\title{
A tracer study of the East African School of Library and Information Science graduates 1995-1999 working in Uganda
}

\author{
Edith Lutwama' \\ and \\ I.M.N Kigongo-Bukenya ${ }^{2}$ \\ East African School of Library and Information Science, Makarere University, Kampala Uganda. \\ lutwama@avu.org and ikbukenya@easlis.mak.ac.ug
}

Received:26 ${ }^{\text {th }}$ April 2003

Revised: $10^{\text {th }}$ March 2004

\begin{abstract}
The study examined the appropriateness of EASLIS curriculum to the professional practice in LIS fields in Uganda. It sought to establish where EASLIS, BLIS and M. Sc. Inf. Sc. graduates work, what they do, and whether their education and training meets employer expectations It further identified areas of the curriculum that need revision. The study was mainly qualitative. Purposeful sampling using the snowball/chain and homogeneous strategies were applied. Methods included focus group interviews, content analysis and observation. The findings reveal that the majority of EASLIS graduates from 1995-1999 are employed in academic, government, banking and NGO libraries where they perform various professional activities; employers complain about lack of practical skills among the graduates, the staff-student ratio is unmanageable and specialization through electives is inadequate. It concludes that the curriculum is slanted towards traditional libraries, though not exclusively; the general nature of the curriculum has met some disapproval; the ever-changing LIS scene demands continuing education (CE); the EASLIS academic staff workload affects staff in doing research and participating in professional activities; ICT facilities still leave much to be desired, practicals are lacking in the current curriculum. It recommends that Information Communication Technology be enhanced in the curriculum; Library and ICT facilities be improved; the curriculum should be market driven; field information professionals should also lecture students; the teaching load should be manageable; and practicals be incorporated in the curriculum; and the Uganda Library Association should be more involved in Uganda Library and Information Education..
\end{abstract}

\section{Background and statement of the problem}

In 1963 the East African School of Librarianship (EASL) was established at the then Makerere University College. In 1995 the name changed to East African School of Library and Information Science to reflect the component of Information Science. The vision of EASLIS is to be an institution of academic excellence in Library and Information Science education, training and research It focuses on creating consciousness about the roles of information in development; training appropriate and competent manpower for the processing and dissemination of information; and development of information workers in the region. Currently EASLIS offers a Certificate in Library and Information Studies (CLIS), a paraprofessional course; Diploma in Library and Information Studies (DLIS) to train middle-level information workers; Diploma in Records and Archive Management (DRAM) to educate and train students in the Archives \& Records Management fields; Bachelor of Library and Information Science (BLIS) to afford students knowledge and skills in managing different types of information institutions; and Master of Science in Information Science (M. Sc (Inf. Sc)) to cater for information specialists and managers.

EASLIS has been training information professionals for over 40 years and her graduates are spread over East, Central and Southern Africa. According to many former students, employers and other stakeholders, EASLIS curriculum needs revision in order to cater for the new changes. Ocholla (2001) points out that tracer studies are important to training institutions since they would enable such institutions to accommodate changes in the society, especially the demands of actual and potential employers, through the evaluation and constant review of the curricula. Few tracer studies have been carried out on Makerere University graduates. One of these is by Kibirige Mayanja (1997), on employment opportunities for Makerere University graduates. It was discovered that the education sector was the largest consumer of these graduates, having absorbed about thirty percent in the schools and universities. The next largest sector was banking, followed by Public Administration and NGOs. Walusimbi (1997) carried out a specific study on job placements of the EASLIS graduates. It revealed that the graduates had acquired insufficient skills; they had had too much theoretical knowledge and less practical know-how; many of the employers stressed the need for more emphasis on IT. This study was limited to placement of EASLIS graduates of 1995 only, and did not examine other related issues.

I. Edith Lutwama is Librarian, East African School of Library and Information Science, Makarere University, Uganda.

2. Issac Kigongo-Bukenya is Associate Professor and Director, East African School of Library and Information Science, Makarere University, Uganda 


\section{Aim and objectives}

The aim of this study was therefore to undertake a comprehensive tracer study with the object of establishing where the EASLIS graduates work, what work they do, competencies demanded by the work they do, and whether the graduates met the employers' expectations in the field and, if not, to establish what areas of the curriculum need to be revisited and appropriate proposals that can be made.

\section{Literature review}

Moore (1988:40-4I) identifies three main types of information professionals: librarians and information officers to establish fairly conventional services in organizations; information specialists to look after the technological solutions to an organization's information problems; and researchers who apply a wide range of skills and abilities to handle information needs in the organization. Approximately seventeen years ago Hayes (1987:139) reported that a high proportion of graduates are finding employment in situations other than libraries. They work in database services, as entrepreneurs, and in small information enterprises, in book publishing and the book trade and in information resource management in government and industry. They also work in other information units such as documentation centres, archives, banks, NGOs and foreign embassies. Myers (1986:656) explains that opportunities exist for database publishers, vendors, computer manufacturers, records managers and many other types of positions in such high-tech fields as micro computing, video-disks, telex, online search specialists, document delivery managers, researchers, systems designers and abstractors.

\section{Required competencies}

There are serious questions concerning the education of information professionals that need serious consideration even beyond the $2{ }^{\text {st }}$ Century. Common questions being asked include: what comprises information studies and what factors affect curriculum development for the education of future professionals? How can the professionals maintain currency and extend their competencies? What do prospective employers expect from graduates of various programmes? Library and Information Science schools have recently emphasised the information element in their curricula. The curriculum changes have been introduced mainly in the expectations of what will be required for careers in the future. It has now become common knowledge that the profession will not only be increasingly reliant on the new technology, but also more diversified. Again Hayes (1987:144) cautions that many practitioners feel that there is too much theory, and too little practice. This could be due to the fact that some library schools do not prepare their graduates for the real world. Educators are of the view that theory and practice should go hand in hand in library education.

What, then, are the qualities and qualifications of information professionals that information industry employers seek and will continue to seek in the future? Fisher and Mcharazo (1993:29I) advise that the basic Masters in Library Studies (MLS) curriculum, especially a one-year programme, cannot prepare a new graduate for all the demands of the first professional job. Specifically for library related jobs, the knowledge and skills required include: knowledge of basic reference sources; ability to conduct a reference interview; ability to develop a search strategy; knowledge of subject sources particularly about the library; ability to communicate orally; ability to write well; ability to communicate with staff; an attitude of service; an attitude germane to making decisions; and an ability to state a problem. A successful manager should be sensitive to the demands of the clients, know the industry of which he is a part, and should be close to the clients' needs. Smith (1990:43) observes that employers expect graduates to have first-rate minds with problem-solving abilities, a solid undergraduate preparation with emphasis on training rigour, concrete evidence of managerial abilities and an intellectual commitment to research librarianship. Preschel (1988:358) asserts that enthusiasm, intelligence, education, flexibility, ambition, computer literacy, good judgment, hard work, an innovative approach to problem solving, and a desire to serve top the list and will continue to do so. He emphasises that the most important personal characteristics that an information industry employer looks for in a new employee are a logical and orderly mind, the ability to learn from experience, and the ability to extrapolate from learned experience, the ability to view things realistically, to project possible outcomes, causes and results and to choose the course of action most likely to bring about desired outcomes. The knowledge and skills most current employers frequently want in Uganda are computer and foreign language skills and knowledge of business or of a science, and these should be updated by formal continuing education or by on-the-job training. The ability to use a computer is considered a basic skill. Computers are used in information units in everything from record keeping to report writing, database building, accounting, archival management, information retrieval, circulation management, cataloging and desk-top publishing. From Moore's (1996:25) point of view, a new employee is expected to know how to use computers, how to learn new programs or even how to do a little programming and how to use the major online database vendors. 
Johnson (1997:154) suggests that educators must make greater efforts to inform the practitioner about their efforts to keep the curriculum up-to-date and relevant, and that professional skills are needed to manage a successful site on the World Wide Web. 'Decision makers do not have the time to search for information and so require professional support by people who can understand the task efficiently and effectively in the fields of business management, health care and public policy making' (Waddington, 1996:154).

Analysing leadership for information professionals, Raseroka (1998) stresses that we must prepare syllabuses that incorporate new management skills and techniques in financial, personnel and organisational management. Leadership skills in facilitating in-service training, staff development and mentorship programmes are essential for management of change. Technical skills are necessary for the effective manipulation of ICT and for developing expert knowledge to meet local and evolving ICT needs. Communication with students, teaching colleagues and among staff within the institution is the responsibility of every professional. Alongside these practical skills, Levy (1992:157) sums up that for the information professional to play an effective role within the organisation, $s /$ he will need the right attitude and personal qualities, good interpersonal skills, leadership skills and an understanding of user empowerment. It is therefore not surprising that Usherwood (1987:8) advises that we should aim to produce young professionals with the ability to make and present a case, young librarians with decision making, problem solving and communication skills. Such skills are developed not just by course content, but also by using learning techniques which encourage analysis, argument and creativity. So experiential learning, role-playing, case studies and exercises should play a major role in our programmes. Students should be given the opportunity of learning to question and also questioning practitioners, community workers, politicians and all others connected to the information world.

\section{Appropriate curriculum for information professionals}

Saunders (1978:23) points out that LIS is a vocation and should therefore normally include a practical component, and allow for the acquisition of skills, which are relevant to the profession in question. Today it is emphasised that the curriculum designer should consider the geographical area, the intended level of training and the target group, the language of instruction and the nature and content of the curriculum. Looking to the future, Johnson (1998:157) suggests that we must develop a new generation of information professionals who are willing and able to learn, who recognise the need for continuing their professional development and who are motivated towards it. Unfortunately, the emphasis in LIS schools has been on teaching and developing technical competencies, rather than on developing students' ability to learn. Therefore the training institutions have to consider not only the content of their courses but also the impact of their teaching, learning and assessment methods in preparing the new information professionals. Rosenberg (1994:6) points out that no curriculum is static; it must be open to review and revision as the field of information science is expanding at a rapid pace. New specialisation and professional practices are arising worldwide, which need to be incorporated into the curriculum. Therefore the Uganda curriculum should not merely mirror a curriculum for the USA or UK, but must meet the needs of Uganda and ensure that its graduates have the professional competencies currently required by employers. It must keep abreast of changes in the market.

The study by Rosenberg ( 1994) reveals that content or teaching methods must aim to generate such abilities including: creative thinking and the production of new ideas; working independently; adaptability and flexibility; judging between alternatives; and positive attitude to work It is emphasised that an appropriate curriculum must include relevant professional experience, so as to enable and allow theory to be put into practice and to enable practice to modify theory. Moore (1987:31) stresses that in developing these new curricula, it is not sufficient simply to add bits to existing courses. What is called for is a root-and-branch re-examination of the skills and expertise called for by the new employment markets. Only when such an examination has been carried out is it possible to initiate the curriculum development and design process which will produce the courses in turn, and produce the graduates capable of entering the new markets. It is common belief among LIS educators today that the finest curriculum that can be produced is of little or no use if staff of the right calibre and in sufficient numbers is not available to teach it. The IFLA Standards for Library Schools (KigongoBukenya (200I:315) lay down one staff member for every twelve students. A minimum of $4-6$ full time staff are required regardless of the number of students, to provide for coverage of basic subjects, because the poorer the level of staffing, the more narrow the curriculum and the way it is taught. It is advised that any library school will gain effectiveness if it can call upon the part-time services of experienced senior practitioners, either for occasional lectures or for a whole course of lectures on their particular specialisation Their contribution from a 'live' operational unit brings a vigour and authenticity to their teaching which is much appreciated by students. Their contribution enriches the curriculum by including a wider range of topics than would be feasible if the teaching force were restricted to a small number of full time staff. He further suggests that it would be highly artificial if a curriculum included a component concerned with computerisation without access to a computer and an appropriate range of peripheral equipment, where the students are 
able to have actual 'hands-on' experience of its operation. He therefore urges a strong case for making a 'laboratory' an essential feature in any programme of professional education. There should be adequate resources of skilled technical manpower for maintenance purposes, in introducing students to the new technologies.

\section{Information Technology}

Few professionals who qualified more than five years ago had formal training in the information technology skills required in modern libraries. Most of the recently qualified staff had only a minimal level of computer literacy. The recent review of LIS Schools suggests that major revisions are required in the curriculum to meet the information technology needs of the profession. ICT has become a significant factor in most library and information work, but especially for posts in the emerging market. It has enhanced the productivity of the professionals and required them to learn a wider range of skills because employers had a range of necessary skills in mind when they appointed staff. There was a need by LIS Schools to revise present curricula extensively if they intended to aim seriously at emerging markets for graduates. ICT was identified as one of the four important areas where graduates needed more skills in order to compete. As Aina (1992) indicates, ICT skills are required for competence in electronic document delivery and digitisation of local databases, all of which support the core business of academic libraries.

\section{Continuing Education (CE)}

If the profession was to expand its share of the information provision job market, there had to be a thorough reexamination of the courses provided by the schools of LIS, and the continuing education component had to be a major element in this re-examination.

From Watson's (199I:3) experience, CE at the professional level is concerned mainly with the maintenance and improvement of the competence and performance of persons of a particular profession. Through CE programmes, persons can narrow the gaps in their professional undertaking, keep abreast of new trends, update existing skills and techniques, improve upon how they perform their daily tasks and also contribute to the existing pool of professional expertise. CE is also important not only for disseminating information about new developments to peers and colleagues, but it is also necessary as no School can cover all professional needs, nor can any initial training satisfy the many changes that occur during the span of one's professional life. The responsibility of CE should rest on individuals, institutions, associations, and employees concerned with the profession. Commenting on CE, Kigongo-Bukenya (1999:95) outlines the objectives of $\mathrm{CE}$ as: keeping up with new knowledge of the profession; adjusting to new conceptions of the profession; continuing to study the basic supporting discipline of the profession and personal development as an individual, not just as a professional. CE programmes at EASLIS are conceptualised both in terms of improving basic education and acquiring higher qualifications to improve one's professional status, and as a means of meeting the Code of Ethics requirement to keep oneself up-to-date with theory and practice in the profession to provide the best effective services to the users.

\section{Methodology}

A qualitative research design was applied to allow in-depth study of the population. The approach was phenomenological and the emphasis was on describing the experience from the participants' perspective. Purposeful sampling was employed and within this framework, the snow-ball/chain and homogeneous sampling strategies were applied to locate information-rich cases. The snowball strategy aimed at establishing the best rich information sources through inquiry from renowned LIS lecturers, employers, who revealed individuals who would give best answers to the issues that were being researched. The homogeneous strategy handled focus group discussion involving stakeholders with some expertise and possibly experience and interest as a group, for example LIS lecturers, students and employers.

A manageable sample of 60 was selected from a population of 217 respondents. The composition of the sample frame was as follows:

- Forty-two BLIS and M. Sc. Inf. Sc. EASLIS graduates derived from the EASLIS student graduation lists of the respective years under study;

- Nine employers corresponding to the biggest institutions employing EASLIS graduates. The employers were picked because they are key to assessing the graduates and consequently to gauge the relevance or otherwise of the competences and skills taught by EASLIS;

- Eight lecturers because they teach theory and practice to the students; and the Secretary of the Uganda Library Association because of its concern with LIS education and training.

Patton (1990:187) reveals that no single method can adequately solve the problem of rival causal factors, as each method reveals different aspects of empirical reality. Therefore, triangulation of methods was applied in order to ensure accuracy of data. The methods used included observation to examine programme operations and understand better the context 
within which the programmes operate; the focus group discussion involving face-to-face interaction between individual respondents leading to self-report; and content analysis to analyse literature related to the study. Corresponding instruments used included: the questionnaire distributed to correspondents, interview guide highlighting issues to be probed, the focus group discussion guide specifying the management of the focus discussion, and various information sources including the Internet.

In analysing data, the heuristic process of phenomenological analysis was followed. Kigongo-Bukenya (200I:I8I) discusses the Moustakas phases of data analysis, which were followed in analysing the data of this research. These were: immersion to familiarise and cross-check that all data was in place; incubation and the identification, coding and categorising of data; illumination - the contextualising of the experiences and opinions gathered during research; explication - the explaining of the dimensions of meaning to give a holistic view of the issues explored in research; and creative synthesis to reconcile all the above steps, make interpretation and identify realistic recommendations for the way forward.

Manual analysis of data was preferred because it brought closeness and knowledge about the data and facilitated effective interpretation of the data and the drawing of conclusions according to the vividness gathered from the respondents by the researcher, which could not be effectively handled by SSPS.

\section{Presentation and discussion of findings}

The qualitative methods and the nature of instruments used in the study encouraged open discussions from the sampled participants and gave plenty of data based on knowledge and experience of the subject under study. Several methods and sources were applied to generate data, which provided an in-built quality control to ensure genuine data. The sample of participants was representative of a cross section of stakeholders and ensured various views. However, some problems were encountered. For example, 20\% (twelve out of sixty correspondents) of the respondents, for unspecified reasons, did not respond to the questionnaires. Some answers in the returned questionnaires did not make sense, while others were not properly filled in. Sometimes the respondents had to be reminded before they reacted. One scheduled interview never took place because the interviewees were 'too busy'. Notwithstanding the above problems, the return rate of $80 \%$ (forty eight or sixty correspondents, a break-down of which has been earlier explained) was satisfactory and represents the majority view. Findings are presented and discussed under the subtopics corresponding to the objectives of the study. The total sample population was sixty.

The return rate of active sampled population was forty-two an equivalent of $80 \%$, and consisted of twenty-four graduates, nine employers, eight academic staff and the Secretary of Uganda Library Association.

\section{Where EASLIS Graduates Work}

The majority of EASLIS graduates, sixty-five percent, are employed in academic institutions, with Makerere University absorbing the largest number followed by Mbarara and Kyambogo Universities. The private universities are also absorbing many EASLIS graduates. It was noted that universities attract more EASLIS graduates because they have wellestablished libraries with reasonable remuneration for staff. Twenty-six percent work in government organisations; $5 \%$ work in banking institutions and non-governmental organisations respectively. The last two institutions employ the least graduates because they have small libraries and the institutions themselves are few. Other employing institutions included private school libraries, tele-centers, newspaper houses, publishers, printers, binderies, foreign missions, special libraries, commissions and hospitals. The non-government institutions offer more attractive terms of service and have better facilities such as offices and ICT facilities.

\section{What EASLIS graduates do}

Fifty percent work as librarians, while ten percent work as assistant librarians and library assistants respectively. Furthermore, five percent work as data editors, librarian trainees and records officers respectively. Different organisations use different titles for their information officers. Titles identified included: sales managers, systems analysists, data bank managers, book production managers, public relations officers, lecturers and newspaper editors. The implication is that there is a need for an interdisciplinary curriculum in order to produce graduates with a competitive edge in the emerging market. Currently many graduates work in traditional libraries. Fifty percent expressed a need for an ICT curriculum.

The majority of the information units provide information through books or journals. Some libraries offer online searches. CAS and SDI services are offered by 13\%. Searching databases is offered by nine percent as are consultancy services and Internet services. 'Others' had a tally of $9 \%$. Further, the employers were asked which services the graduates learnt on the job. Those cited included administration, database and online searching, electronic archival processing, information retrieval techniques and library management routines. The implications for the EASLIS 
curriculum are clear. First, there is an urgent need to reflect the above established competencies and skills in the curriculum. Second, EASLIS should have more practical exposure to meet the complaint that graduates take their first appointments without appropriate skills demanded by the employers.

\section{ICT training at EASLIS}

When the respondents were asked about the ICT component of the EASLIS curriculum, the majority of respondents (87\%) were not satisfied, because the education and training received was largely theoretical and some of the lecturers were not very experienced. As a result, graduates lack sufficient practical experience in ICT. This perhaps explains why many graduates have had to take extra training in ICT skills on leaving EASLIS. Internet connectivity and the student computer ratio of I:30 ( 15 computers serving a student population of 450) are incredibly high. These are complicated by high costs of connectivity and maintenance, which means students cannot have adequate hands-on experience.

\section{Competencies required of EASLIS graduates}

When the ten employers, the nine academic staff and the Secretary of the Uganda Library Association were asked what competencies were expected of the new Information Professionals, they concurred with EASLIS graduates. Competence, innovation, flexibility to change, self-supervision and personality scored twenty two percent as skills most required. From the employers' point of view $22 \%$ pointed out that background in computing and management studies carry more prestige than library and information studies. Communication skills were mentioned by $11 \%$. Other skills needed were expressed by $45 \%$ and included relevant training and qualifications for the job, broad-mindedness, the ability to formulate solutions and the ability to conceptualise issues.

\section{Perception of EASLIS curriculum}

When asked about their perception of the EASLIS education and training of the information professionals, $55 \%$ of the respondents thought that it should reflect the emerging information needs. Eleven percent indicated that training lacked management skills elements and that this should be addressed. Equal percentages commented that training lacked adequate practical training and further complained that the curriculum was too theoretical. Sixty percent of the correspondents expressed the view that specialisation should be embraced. This contradicts Nawe's caution (1992:12 'For a new information worker in Africa, the job opportunities currently available do not make it advisable for students to specialise in any one area ... the training offered should prepare one to work in any big or small information unit as well as prepare one to work in any complex environment'.

\section{Revisiting EASLIS curriculum to suit the information professional of the $2 \mathbf{I}^{\text {st }}$ Century}

When the 42 returned questionnaires from graduates, employers, academic staff and the Secretary of the Uganda Library Association were analysed, $30 \%$ expressed the need for curriculum revision with more emphasis on ICT. Twenty percent suggested that due to the increasing student population, teaching and research facilities like computers and lecture rooms should be improved accordingly. Fourteen percent suggested that EASLIS should employ competent part time lecturers from related disciplines to broaden the curriculum with their experience. Fourteen suggested that more staff members should be recruited so as not to overburden the ones on the ground. One percent of the respondents revealed that courses like psychology, law, accounting, and entrepreneurship should be introduced in the curriculum, as some employers required them. Thirty-five percent expressed the need to involve stakeholders when revising the curriculum. As emphasised by Kigongo-Bukenya (200I), in these times of rapid professional and technological change, a basic course of study does not last for life. It must be complemented by CE programmes which have the role of 'updating', of giving scope for specialised study in greater depth. The respondents were asked whether they had attained further education in any courses after graduating from EASLIS. The information obtained reveals that some of them had taken courses in personnel management, computer science, records management, information and retrieval systems to improve on their skills. It was further established that the external examiners have been instrumental in highlighting the urgency of revising and innovating curricula. Consequently the EASLIS Board of Studies launched new programmes such as the Diploma in Records and Archives Management and revised both the Certificate Diploma and Bachelor's programme to attune them to the LIS changing market.

\section{Related issues}

The study took a holistic approach and looked at other factors that could have an influence on the curriculum. The following discussion focuses on such factors. 


\section{Qualifications and experience of EASLIS lecturers}

When asked about the performance of EASLIS lecturers, $63 \%$ of the respondents revealed that the lecturers taught well. However, $37 \%$ indicated that the lecturers taught only fairly well because they lack experience and did not cover the subjects deeply. All the respondents suggested that lecturers' overload should be reduced. Vacant posts should be advertised and filled by subject specialists. Consequently the workload would be reduced and the lecturers would find more time for teaching, conducting and supervising research.

The study also wanted to establish whether EASLIS lecturers had adequate qualifications and experience to impart the necessary skills. The School establishment is fourteen academic staff. Three of them are Associate Professors; three are $\mathrm{PhD}$ holders. A policy setting a PhD as a minimum qualification for Lecturer was adopted in 1998. Since then there has been frantic registration for PhDs. Consequently two more senior academic staff have registered for the PhD. Research proposals have been accepted from two Assistant Lecturers and their registration is pending funding. The School has been fortunate because all the academic staff except one have joined after LIS working experience in different library and information services and systems, and so carry a lot of practical experience, which enriches their teaching. For example the current Director has 15 years' working experience as Librarian and Deputy Director of the National Library Services. Others have worked as librarians in the University and special libraries at different levels.

\section{EASLIS Library}

As early as 1978, Saunders commented that in subjects as dynamic and wide-ranging in scope as Library and Information Science, a large and well-stocked library is an indispensable requirement for effective teaching and leaning.

Respondents were asked to comment on the EASLIS Library. Sixty percent of the respondents revealed that the library was inadequate in stock, sitting space and up-to-date reference materials. Twenty percent expressed the need for Internet services in the Library. Seventeen percent suggested the need for the introduction of audio-visual materials in the Library, while three percent suggested that the periodicals' section should be improved. It was also expressed that the library should represent in its stock what is going on elsewhere on the international scene. Lecturers were also asked to comment on the library stock. Sixty-six responded that the library was not adequately stocked. The rest were somehow satisfied.

\section{Linkages}

On whether EASLIS had any academic linkages, respondents revealed that linkages exist with Moi, Dar-es-Salaam, Nairobi and Kenyatta Universities. Linkages are being negotiated with the MA Information Studies Programme, the Valdosta State University and the School of Library and Information, University of Tennessee. Areas of linkage involve exchange of academic staff and students, joint development of courses, joint research and publication and initiation of elearning. The linkages would enrich programmes, facilitate students' exposure and allow staff interaction and sharing of ideas on issues unique to the profession.

\section{Mechanism of up-dating curriculum}

When the respondents were asked whether there was any mechanism to update the EASLIS curriculum, $80 \%$ were aware that such a mechanism was in place. The rest were not sure. It was established that EASLIS Board of Studies, the Humanities Committee, the Senate and the University Council usually carry out this exercise. The last major revision was effected in 1997 on the CLIS, DLIS and BLIS programmes to bring them in line with the Semester System.

\section{Mode of assessment}

On the mode of assessment of students' performance, the respondents answered that this was done through assignments, examinations, and research. It was further revealed that projects and attachments were also used to assess students. Every end of the semester, students complete evaluation forms on each course offered. Aspects of evaluation include the performance of the lecturers, quality of content, methods of teaching and related issues including facilities, space and academic environment.

\section{Conclusions and recommendations}

The following conclusions were made:

- The majority of EASLIS graduates are employed in traditional libraries as librarians, information officers or records managers. The EASLIS curriculum targets knowledge, competencies and skills, slanted, although not exclusively, to these libraries.

- The general nature of the EASLIS curriculum has met some disapproval because graduates do not cope with work in specialised libraries including documentation, records and archives centres, registries, banking institutions, etc.

- The predominance of theory in the curriculum is a problem to graduates at their new work places because they lack 
the practical skills and have to undergo lengthy in-service training before they settle down in their new jobs. This is particularly a serious issue since many of the newly graduates get employed directly in one-person libraries, meaning that they learn skills through trial and error.

- The ever-changing LIS scenario requires graduates to undertake continuing education (CE) courses.

- The current EASLIS lecturers' workload does not allow them adequate time to effectively prepare lectures, organise seminars and tutorials, undertake private study and research in order to keep themselves abreast of developments within the profession.

- Lack of ICT facilities does not allow students adequate hands-on experience to effectively participate and give services in the ICT environment.

- A good library and information school/department of a regional or international repute must have a well-organised library/information centre with varied, up-to-date and adequate stock in terms of quality and quantity.

The following recommendations were made:

- EASLIS curricula should be revised to ensure that the programmes are market driven. Further specialised courses should be offered to help graduates to work nationally and internationally as subject specialists and consultants.

- Information professionals from a variety of information related occupations should be employed as part-time lecturers as these have the advantage of bringing current practical experience into the classroom and should ensure a firm link between the academic and the practitioner and between theory and practice. Further, students should be encouraged to visit information institutions and industries.

- The staff-student ratio should be manageable to allow staff to teach, carry out research, publish and be involved in professional issues. Teaching assistants should be recruited to assist the students with their course work, seminars and tutorials. It is necessary that the academic staff have opportunities to attend refresher courses or full time study and research in order to keep them up to date with the knowledge of their subjects.

- Practicals should be a compulsory component of the programmes to enable students put theory into practice.

- The Uganda Library Association should get more involved in LIS education by way of setting up standards and an accreditation system.

- The curricula should reflect, and remain responsive to, the changes taking place in the information world, the application of ICT to information handling and training of information professionals as managers of information services.

\section{References}

Aina, L. O. (1992) The training of New Information Workers for Africa Today: Proceedings of the $10^{\text {th }}$ Standing Conference of Eastern, Central and Southern African Librarians. Dar-es-Salaam, $27^{\text {th }}$ July - IAugust:

EASLIS Graduand Lists of Academic years 1995/6, 1996/7, 1997/98 and 1999/200

Fisher, W. and Mcharazo J. M. (1993) "The Information professional". Library Trends. Volume 42, Number.2:

Hayes, R. M (1987) "Education of the Information Professional: a Library School perspective." Journal of the American Society for Information Science. Volume. 39 Number 5: I30-145

Johnson, I. M. (1997) "Challenges in developing professionals for the information society: and some responses by the British schools of Librarianship and Information studies." Library Review, Volume 47, Number.3:153-165

Johnson, I. M. (1998) "Peering into the mist and struggling through it: the education and training of the future information professional." Library Review, Volume. 47, Number.3: 183-190

Kibirige-Mayanja, M. (1997) Employment opportunities for Makerere University graduates; a tracer study. Kampala; Makerere University.

Kigongo-Bukenya, I. M. N. (200I:205). A Library and Information Curriculum for Uganda with Special reference to the East African School of Library and information Science, Makerere University: A Study of Influences and Processes in Curriculum Development. (PhD Thesis, University of Wales.)

Kigongo-Bukenya, I.M.N (1999) "New Trends in Library and Information fields and the Implications for Continuining Education." Journal for Librarianship and Information Science, 31, (2) June, 1999.

Levy, P. (1992) "'People skills: interpersonal skills training for library and information work". Library Review, Volume.47, Number 3: 150-163

Moore, N. (1987). The Emerging Markets for Librarians and Information Workers. Library and Information Research Report 56. London, British Library Board.:31.

Moore, N. (1988) 'The emerging markets for librarians and information workers'. Library Review, Volume.47. Number.3: 38-42

Moore, N. (1996) "Creators, communicators and consolidators; the new information professionals in managing information". ASLIB Information, Volume. 16, Number. 2, 1996: 24-26

Moustakas, C. (1990) Heuristic Research: design and methodology and application. Newsbury Park, CD Sage.

Myers, M. (1986) 'The job market for librarians'. Library Trends. Vol.34. no. 4: 656-66I

Nawe, J. (1992) Training of New Information Worker in Africa. Proceedings of the $10^{\text {th }}$ Standing Conference of Eastern, Central and Southern African Librarians. $27^{\text {th }}$ July - I ${ }^{\text {st }}$ August, Dar es Salaam.

Ocholla, D.N. (200I) Curriculum Response to a Changing National and International Information Environment: Theoretical and Methodological Paradigms on Review and Revision. Education for Information, Vol. 19, No 2:143-168

Patton, M.Q. (1990) Qualitative evaluation and research methods, $2^{\text {nd }}$ ed. Newbury Park: Sage Publications. 
Preschel, B. M. (1988) "Education of the information professional: what employers want". Journal of the American Society for Information Science. Vol.39. No.5: 358-36I

Raseroka, H.K. (1998) Skills for Information Professionals in Academic Libraries in Sub- Saharan Africa: proceedings of the $10^{\text {th }}$ Standing Conference of Eastern, Central and Southern African Librarians. $27^{\text {th }}$ July - $\left.\right|^{\text {st }}$ August, Dar es Salaam

Rosenberg, D. (1994). Achieving the optimum curriculum: a survey of the BSc. in information sciences curriculum in the context of information needs in Kenya, Moi University, Eldoret

Saunders, W.L. (1978) UNISIST Guidelines for Curriculum Development in information Studies. Paris: Unesco.

Smith, N. M. (1990). Educating future librarians: the library School perspective. In: Library education and employer expectations. New York: The Haworth Press.

Usherwood, B. (1987) Education for Public Librarianship: the crisis and the challenge. $53^{\text {rd }}$ IFLA Council and General Conference, Brighton, U.K. $16^{\text {th }}-21^{\text {st }}$ August.

Waddington, P. (1966). "Is there any knowledge out there?" Library Review Vol.47 no 3 : I5I-160

Walusimbi, Brenda (1997), Job Placement of the Graduates of the East African School of Library and Information Science. Dissertation in Partial Fulfillment of the Requirements for the Award of the Degree of Bachelor of Library and Information Science, Makerere University.

Watson E (199I) "After the degree: continuing education in the Commonwealth Caribbean Librarians." COMLA Newspaper, Number 73: 3-5

Woodworth, A. In: Thapisa, Amos (1999). "Developing Lasting Competencies for a $21^{\text {st }}$ Century, Information Economy Workforce." Library Management Volume 20, Number 2: 93

\section{APPENDIX I - A SURVEY OF EASLIS GRADUATES, EMPLOYERS, ACADEMIC STAFF AND SECRETARY OF UGANDA LIBRARY ASSOCIATION ON THEIR OPINION ON THE APPROPRIATENESS OF EASLIS CURRICULUM AND RELATED ISSUES}

\section{QUESTIONNAIRE}

(a) Use space provided to write your answer to the questions. You may use additional paper where necessary. Please tick the corresponding box where applicable. If the question does not apply, write N/A

\section{PERSONAL BIODATA}

Surname

Other names

Name of Institution

Address

Telephone

Fax: E-mail

\section{EMPLOYMENT RECORD}

3. What is your job designation?

4. What type of organization are you working in?

5. What professional activities are you engaged in?

[ ] Book processing (cataloguing and classification)

[] Database searching

[ ] Online information retrieval

[] Research

[] Others (specify)

6. Which of these skills did you acquire from EASLIS?

(Give comments)

\section{EDUCATION AND TRAINING}

7. Have you attained any further education/training after EASLIS Yes [ ] No [ ]

If yes, please indicate name of the course and reasons for taking it.

8. What would be your remarks on EASLIS academic environment?

(a) Assignments/ course work?
[] Excellent

[1]

(Give remarks)

(b) Lecturers
[] Excellent [] Good
[ ] Fair
[] Poor
(Give remarks)

(c) Practical lectures

[ ] Excellent [] Good [] Fair [] Poor 
(Give remarks)

(d) Theoretical lectures

[] Excellent [] Good [] Fair [] Poor

(Give remarks)

(e) Students' seminar papers

[] Excellent [] Good [] Fair [] Poor

(Give remarks)

(f) Others (specify)

(g) How do you assess the provision of relevant reading materials in the Library?

[] Excellent [] Good [] Fair [] Poor

(Give comments)

\section{INFORMATION TECHNOLOGY}

Are you satisfied that the ITcomponent in your curriculum during your training adequately prepared you for your present job environment?

[ ] Very Satisfactory [ ] Could not say [ ] Not satisfied.

If satisfied, please state the tasks in which you have utilized IT. If not satisfied, please give your reasons.

\section{EASLIS CURRICULUM}

(a) Which of the following courses offered at EASLIS have you have found relevant to your working environment? (Tick appropriate box(es)

COURSES:

Automation of Library and Information Services

Basics Accounts

Basics of Information Work

Bibliographic Control

Book Production, management and Book trade

Database Management

Desk Top Publishing

Geographic Information Systems

Information Industry and Information Resources

Information Organization and Processing

Information Skills and Technical Writing

Information Technology and Retrieval Systems

Legal Information Systems and Services

Library Management, Administration and Routines

Marketing and Public Relations

Media Technology Organization

Programming

Publishing Management and Editing

Records Management and Archival Administration

Research and Qualitative Methods

Research Project.

Systems Analysis and Design

(b) How have these courses been relevant to what you are doing?

(c) What competencies are expected at your work environment?

(d) What courses do you feel should have been covered which were not included on the curriculum?

(e) What is your opinion about EASLIS Curriculum?

\section{STRENGTHS}

\section{Weakness}

Give suggestions on how to make EASLIS curriculum relevant information professional in Uganda today

Explain whether the education you received at EASLIS is appropriate to your professional requirements. (Give reasons) 


\section{APPENDIX 2 - A SURVEY OF EMPLOYERS, ACADEMIC STAFF, GRADUATES AND SECRETARY OF UGANDA LIBRARY ASSOCIATION TO ESTABLISH COMPETENCIES EXPECTED FROM EASLIS \\ GRADUATES}

I. Name of Institution

$$
\text { Address }
$$

Telephone

Fax E-mail

2. What type of Information unit are you working in?

3. What kind of Information Services do you offer?

Tick appropriate boxes)
[] Books
[] Journals
[] Consultancies
[] Current Awareness Services (CAS)
[ ] Selected Dissemination of Information (SDI)
[] Database Searches
[ ] Online searches
[ ] Others (specify)

4. Which of these did the graduates learn on the job?

5. How do you rate your staff that graduated from EASLIS in connection with the following:

(Indicate appropriate box)

[1] Excellent [2] Good [3] Fair [4] poor
(a) Management kills []
(b) Database searching [ ]
(c) Online retrieval skills []
(d) Book processing []
(e) Communication skills []
(f) Others (specify)

(Give remarks)

6. What skills do you always look for when recruiting Information Professionals?

7. What is your perception of the training received at EASLIS?

8. Given the opportunity, how would you design the curriculum at EASLIS to meet the challenges of the 2 Ist Century, and beyond?

(Give reasons) 